\title{
AMYLOLYTIC ENZYMES - FOCUS ON THE ALPHA-AMYLASES FROM ARCHAEA AND PLANTS
}

\author{
ŠTEFAN JANEČEK ${ }^{1,2}$ \\ ${ }^{I}$ Department of Biotechnology, University of SS. Cyril and Methodius, J. Herdu 2, \\ SK-917 01 Trnava, Slovak Republic (Stefan.Janecek@ucm.sk) \\ ${ }^{2}$ Institute of Molecular Biology, Slovak Academy of Sciences, Dúbravská cesta 21, \\ SK-845 51 Bratislava, Slovakia (Stefan.Janecek@savba.sk)
}

\begin{abstract}
Amylolytic enzymes represent a group of starch hydrolases and related enzymes that are active towards the $\alpha$-glycosidic bonds in starch and related poly- and oligosaccharides. The three best known amylolytic enzymes are $\alpha$-amylase, $\beta$-amylase and glucoamylase that, however, differ from each other by their amino acid sequences, three-dimensional structures, reaction mechanisms and catalytic machineries. In the sequence-based classification of all glycoside hydrolases (GHs) they have therefore been classified into the three independent families: GH13 ( $\alpha$-amylases), GH14 ( $\beta$-amylases) and GH15 (glucoamylases). Some amylolytic enzymes have been placed to the families GH31 and GH57. The family GH13 together with the families GH70 and GH77 constitutes the clan GH-H, well-known as the $\alpha$-amylase family. It contains more than 6,000 sequences and covers 30 various enzyme specificities sharing the conserved sequence regions, catalytic TIM-barrel fold, retaining reaction mechanism and catalytic triad. Among the GH13 $\alpha$-amylases, those produced by plants and archaebacteria exhibit common sequence similarities that distinguish them from the $\alpha$-amylases of the remaining taxonomic sources. Despite the close evolutionary relatedness between the plant and archaeal $\alpha$-amylases, there are also specific differences that discriminate them from each other. These specific differences could be used in an effort to reveal the sequence-structural features responsible for the high thermostability of the $\alpha$-amylases from Archaea.
\end{abstract}

Key words: $\alpha$-amylase, glycoside hydrolase families, sequence-structural features, archaebacteria, plants, evolutionary relatedness.

\section{Introduction}

Starch is an important source of energy for a wide spectrum of animals (including humans), plants and microorganisms. It consists exclusively from glucose monomers that are linked by $\alpha-1,4-$ and $\alpha-1,6$-glycosidic linkages. Amylose ( $15-25 \%$ of starch) is formed by $\alpha$-1,4-linearly bound glucoses, whereas amylopectin ( $75-85 \%$ of starch) contains also the branching points with the $\alpha-1,6-$ linked glucoses (LEVEQUE et al., 2000b; BERTOLDO and ANTRANIKIAN, 2002).

Starch industry covers many well-developed and also recently established sophisticated technologies that utilize amylolytic enzymes. These amylases represent approximately $30 \%$ of the worldwide industrial enzyme production, the starch hydrolysis being considered to be the main way of their use (VAN DER MAAREL et al., 2002).

\section{Amylolytic enzymes}

With regard to a complex structure of starch and related oligo- and polysaccharides the starch-degrading organisms have to dispose by relevant 
combination of starch hydrolases and related enzymes (LEGIN et al., 1998; BERTOLDO and ANTRANIKIAN, 2002). These enzymes are in general called amylases.

The amylolytic enzymes form a large group of starch hydrolases and related enzymes that are active towards starch, pullulan, glycogen and other related oligo- and polysaccharides (VIHINEN and MANTSALA, 1989; PANDEY et al., 2000; JANECEK, 2009). It is a common way of binding of a glucose residue of the substrate in the enzyme active centre, termed conventionally as a substrate-binding subsite (DAVIES et al., 1997), that is responsible for the activity of amylolytic enzymes. Most of them belong to glycoside hydrolases (GHs) that constitute the individual GH enzyme families without mutual sequence similarities (HENRISSAT, 1991). Now the GH families are part of the CAZy web-server (CANTAREL et al., 2009) that covers also other carbohydrate-active enzymes (Fig. 1).

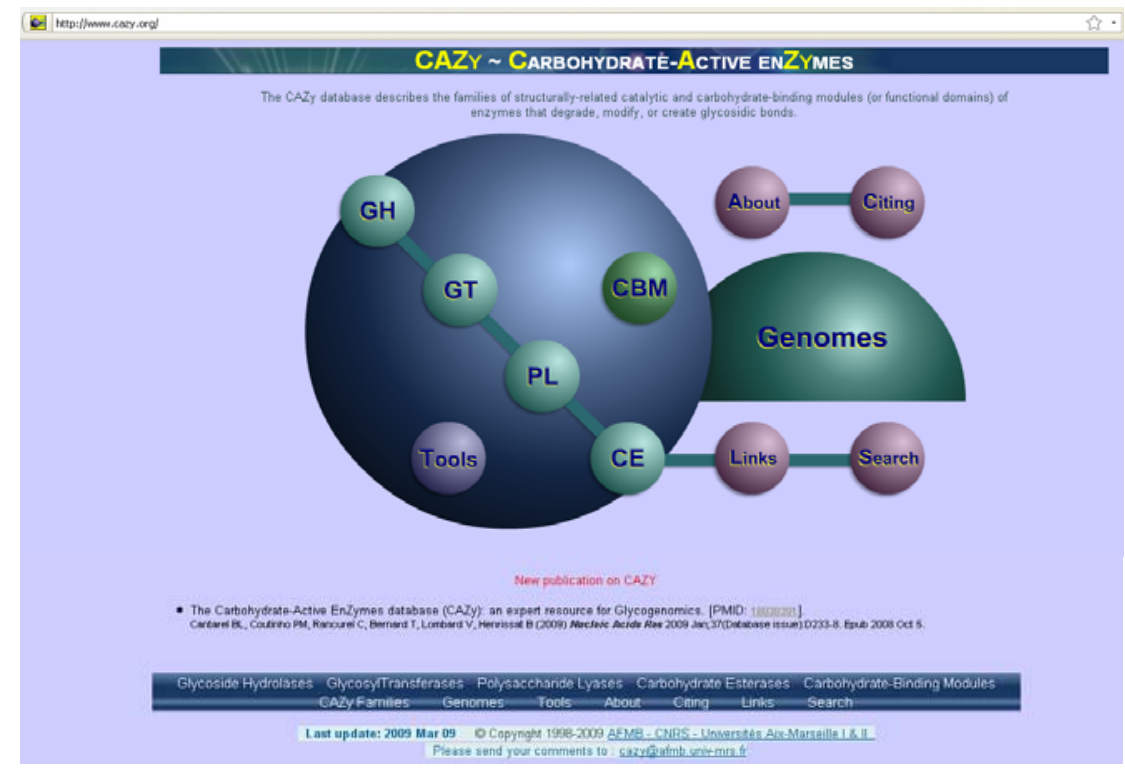

Fig. 1. Carbohydrate-Active enZyme (CAZy) classification (http://www.cazy.org/). The individual proteins and enzymes are within the CAZy server classified into four main groups of sequence-based families: (i) GH, glycoside hydrolases; (ii) GT, glycosyl transferases; (iii) PL, polysaccharide lyases; and (iv) CE, carbohydrate esterases. The CBM stands for the family classification of carbohydrate-binding modules. For details, see CANTAREL et al. (2009).

The most known amylolytic enzymes are $\alpha$-amylase (EC 3.2.1.1), $\beta$-amylase (EC 3.2.1.2) and glucoamylase (EC 3.2.1.3) that are, however, quite different from each other. They differ not only in their primary and tertiary structures, but also in their catalytic machineries and reaction mechanisms employed (JANECEK, 1994a; PUJADAS et al., 1996; COUTINHO and REILLY, 1997). They have therefore been classified into different GH families: GH13 - $\alpha$-amylases, GH14 - $\beta$-amylases, and GH15 - glucoamylases (HENRISSAT, 1991). 
The enzymatic hydrolysis of a glycosidic bond can be characterized by a general acid catalysis that requires two essential components: a proton donor (an acid) and a nucleophile (a base). According to the anomeric configuration of the resulting hydroxyl group with regard to conformation of the cleaved $O$-glycosidic linkage, two basic mechanisms exist for this hydrolysis (Fig. 2): retaining or inverting (MCCARTER and WITHERS, 1994). Whereas $\alpha$-amylase employs retaining mechanism (i.e. the products of its action are $\alpha$-glucans), both $\beta$-amylase and glucoamylase are inverting hydrolases (i.e. they produce $\beta$-glucans).
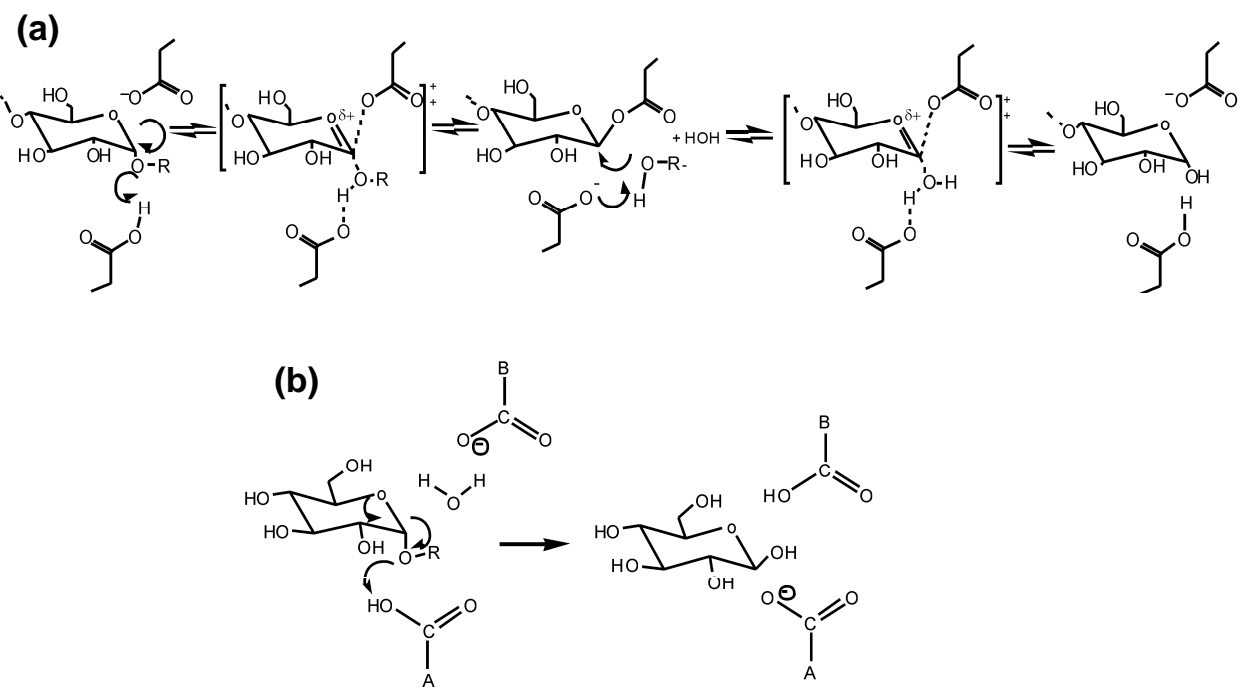

Fig. 2. (a) Retaining reaction mechanism of glycoside hydrolases (MACGREGOR et al., 2001). The proton donor protonates the glycosidic oxygen and the catalytic nucleophile attacks at $\mathrm{C} 1$ leading to formation of the first transition state. The catalytic base promotes the attack of the incoming molecule $\mathrm{ROH}$ (water in hydrolysis or another sugar molecule in trasnglycosylation) on the formation of the covalent intermediate resulting in a second transition state, leading to hydrolysis or transglycosylation product. (b) Inverting reaction mechanism of glycoside hydrolases (SAUER et al., 2000). The catalytic base (top) and acid (bottom) in the water-assisted hydrolysis of substrate leading to inversion of the configuration of the anomeric carbon.

From the structural point of view (Fig. 3), both $\alpha$-amylase and $\beta$-amylase rank among the TIM-barrel enzymes, i.e. they possess the $(\beta / \alpha)_{8}$-barrel catalytic domain, while glucoamylase adopts a helical version of catalytic TIM-barrel, the so-called $(\alpha / \alpha)_{6}$-barrel. Within the CAZy classification the $\alpha$-amylases from the family GH13 with closely related families GH70 and GH77 constitute the clan GH-H that is wellknown as the $\alpha$-amylase family (MACGREGOR et al., 2001; CANTAREL et al. 2009). It is worth mentioning that some $\alpha$-amylases with sequences and structures different from the main GH13 $\alpha$-amylases have been placed to the family GH57 (JANECEK, 2005) and some amylolytic enzymes are present also in the family GH31 (NAKAI et al. 2005; KANG et al., 2008). 
(a)

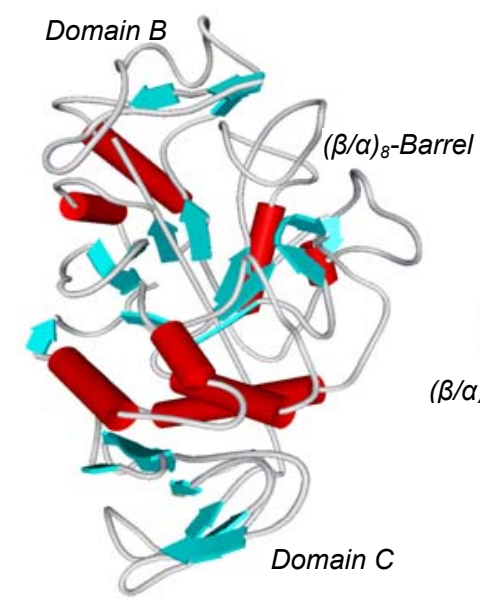

(b)

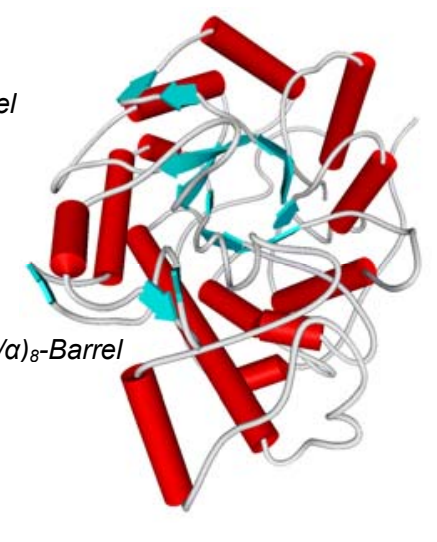

(c)

Fig. 3. Three-dimensional structures of amylases. (a) GH13 $\alpha$-amylase from Aspergillus oryzae (PDB code: 2TAA; Matsuura et al., 1984); (b) GH14 $\beta$-amylase from soybean (1BYA; Mikami et al., 1993) and (c) GH15 glucoamylase from Aspergillus awamori (1AGM; Aleshin et al., 1992).

The catalytic machineries of GH13, GH14 and GH15 $\alpha$-amylases, $\beta$-amylase and glucoamylases, respectively, are also different: whereas the enzymes from the family GH13 possess a catalytic triad formed by two aspartates and one glutamate (UITDEHAAG et al., 1999), both $\beta$-amylases (MIKAMI et al., 1993) and glucoamylases (ALESHIN et al., 1992) have their catalytic machineries formed by two glutamic acid residues that are, however, not alignable due to mutual amino acid sequence differences (PUJADAS et al., 1996; COUTINHO and REILLY, 1997).

It thus could be summarised that amylases and related enzymes classified into the families GH13 (forming with GH70 and GH77 the clan GH-H), GH14, GH15 as well as GH31 and GH57 differ from each other by their amino acid sequences, threedimensional structures, catalytic machineries and reaction mechanism (JANECEK, 2009).

\section{3. $\alpha$-Amylase enzyme family}

Most of amylolytic enzymes are grouped in the $\alpha$-amylase family (MACGREGOR et al., 2001). It was originally recognised as a group of starch hydrolases and related enzymes (such as $\alpha$-amylase, cyclodextrin glucanotransferase, neopullulanase, etc.) that exhibited sequence similarities and commonly predicted TIM-barrel fold (MACGREGOR and SVENSSON, 1989; TAKATA et al., 1992). Within the sequence-based classification of GHs, it was originally established as the family GH13 (HENRISSAT, 1991), but later the families GH70 and GH77 were added to form the presently well-accepted GH-H clan (MACGREGOR, 2005; JANECEK, 2009). 


\subsection{Clan $\mathrm{GH}-\mathrm{H}$}

The above-mentioned families GH13, GH70 and GH77 form the clan GH-H, i.e. the $\alpha$-amylase family, which at present consists of 30 various enzyme specificities (Table 1) and contains more than 6,000 sequences (CANTAREL et al., 2009). The members of the $\alpha$-amylase family are not only hydrolases, but also transferases and isomerases. Based on amino acid sequence similarities, even some heteromeric amino acid transporter proteins may be considered to be the non-amylolytic members of the clan GH-H (JANECEK et al., 1997) (Fig. 4).

Not all family enzymes attack the glycosidic bonds in starch; they are active towards the analogous bonds in glycogen, pullulan and other related poly- and oligosaccharides, like trehalose, sucrose, etc. (MACGREGOR et al., 2001). Whereas the family GH77 is a monospecific family, i.e. it contains only one enzyme specificity - amylomaltase (alternative names 4- $\alpha$-glucanotransferase or disproportionating enzyme; EC 2.4.1.25), the family GH70 consists of two specificties glucosyltransferase (glucansucrase; EC 2.4.1.5) and alternansucrase (EC 2.4.1.140), and the family GH13 is formed by all the remaining enzyme specificies (amylomaltase being also present). GH13 is thus taken as the main $\alpha$-amylase family (MACGREGOR et al., 2001).

Enzymes that are members of the $\alpha$-amylase family have to obey the following four criteria (KURIKI and IMANAKA, 1999; MACGREGOR et al., 2001; JANECEK, 2002; VAN DER MAAREL et al., 2002): (i) they act on $\alpha$-glucosidic bonds (not only the $\alpha-1,4-$ and $\alpha-1,6$-linkages); (ii) they employ the retaining reaction mechanism; (iii) they contain from 4 up to 7 conserved sequence regions; and (iv) they possess the same catalytic machinery within the catalytic TIM-barrel fold consisting of the aspartate residue near the end of the strand $\beta 4$ (catalytic nucleophile), glutamate residue near the end of the strand $\beta 5$ (proton donor) and aspartate residue near the end of the strand $\beta 7$ (transition-state stabiliser).

The conserved sequence regions (Fig. 4) represent the short stretches of amino acid sequence that can be found in every $\alpha$-amylase family member in equivalent positions and that contain the catalytic triad (Asp206, Glu230 and Asp297; Aspergillus oryzae $\alpha$-amylase numbering; MATSUURA et al., 1984) and other functionally important residues (NAKAJIMA et al., 1986; JANECEK, 2002). These conserved sequence regions - common for the entire clan GH-H - may also be used as the sequence "fingerprints" since they contain amino acid residues exclusively specific for the individual enzyme specificities (JANECEK, 2008).

\subsection{Glycoside hydrolase family GH13}

$\alpha$-Amylase is the most known and widely used enzyme of the GH-H clan. In general, $\alpha$-amylases are endo-enzymes specific towards the $\alpha$-1,4-glucosidic bonds, but there are also related GH13 exo-amylases, the so-called maltooligosaccharideproducing amylases (maltogenic $\alpha$-amylase, maltotriohydrolase, maltotetraohydrolase, etc.), preferentially active at one side of the polysaccharide chain producing small oligosaccharides, such as maltose, maltotriose, maltotetraose, etc. (MACGREGOR et al., 2001). 
The $\alpha$-amylase family members are multidomain proteins (Fig. 3a) containing the main catalytic domain in the form of a parallel $(\beta / \alpha)_{8}$-barrel (domain $\left.A\right)$ that is interrupted by a usually small domain in the place of the loop 3 connecting the strand $\beta 3$ with the helix $\alpha 3$ (domain B) and succeeded by the antiparallel $\beta$-sandwich domain (domain $\mathrm{C}$ ). The $\alpha$-amylase-type of the barrel was confirmed in all members of the $\alpha$ amylase family whose three-dimensional structure has already been determined (Fig. 4). The ( $(\beta / \alpha)_{8}$-barrel of $\alpha$-amylases was first revealed in the structure of Taka-amylase A (MATSUURA et al., 1984), i.e. in the structure of the $\alpha$-amylase from Aspergillus oryzae. Since this type of fold was first identified in triose-phosphate isomerase (TIM), the $(\beta / \alpha)_{8}$-barrel is often simply called TIM-barrel (FARBER and PETSKO, 1990). It is a barrel of eight inner parallel $\beta$-strands surrounded outside by eight $\alpha$ helices (Fig. 3a,b).

Table 1. The members of the $\alpha$-amylase family (clan GH-H).

\begin{tabular}{|c|c|c|c|}
\hline Enzyme class & Enzyme & $\mathrm{EC}$ & $\mathrm{GH}$ \\
\hline \multirow[t]{18}{*}{ Hydrolases } & $\alpha$-Amylase & 3.2 .1 .1 & 13 \\
\hline & Oligo-1,6-glucosidase & 3.2 .1 .10 & 13 \\
\hline & $\alpha$-Glucosidase & 3.2 .1 .20 & 13 \\
\hline & Pullulanase & 3.2 .1 .41 & 13 \\
\hline & Amylopullulanase & $3.2 .1 .1 / 41$ & 13 \\
\hline & Cyclomaltodextrinase & 3.2 .1 .54 & 13 \\
\hline & Maltotetraohydrolase & 3.2 .1 .60 & 13 \\
\hline & Isoamylase & 3.2 .1 .68 & 13 \\
\hline & Dextran glucosidase & 3.2 .1 .70 & 13 \\
\hline & Trehalose-6-phosphate hydrolase & 3.2 .1 .93 & 13 \\
\hline & Maltohexaohydrolase & 3.2 .1 .98 & 13 \\
\hline & Maltotriohydrolase & 3.2 .1 .116 & 13 \\
\hline & Maltogenic $\alpha$-amylase & 3.2 .1 .133 & 13 \\
\hline & Maltogenic amylase & 3.2 .1 .133 & 13 \\
\hline & Neopullulanase & 3.2 .1 .135 & 13 \\
\hline & Maltooligosyltrehalose hydrolase & 3.2 .1 .141 & 13 \\
\hline & Maltopentaohydrolase & 3.2.1.- & 13 \\
\hline & Sucrose hydrolase & 3.2.1.- & 13 \\
\hline \multirow[t]{9}{*}{ Transferases } & Amylosucrase & 2.4.1.4 & 13 \\
\hline & Glucansucrase & 2.4.1.5 & 70 \\
\hline & Sucrose phosphorylase & 2.4.1.7 & 13 \\
\hline & Glucan branching enzyme & 2.4.1.18 & 13 \\
\hline & Cyclodextrin glucanotransferase & 2.4.1.19 & 13 \\
\hline & 4- $\alpha$-Glucanotransferase (Amylomaltase) & 2.4 .1 .25 & 13,77 \\
\hline & Glucan debranching enzyme & $2.4 .1 .25 / 3.2 .1 .33$ & 13 \\
\hline & Alternansucrase & 2.4.1.140 & 70 \\
\hline & Maltosyltransferase & 2.4.1.- & 13 \\
\hline \multirow[t]{3}{*}{ Isomerases } & Isomaltulose synthase & 5.4 .99 .11 & 13 \\
\hline & Maltooligosyltrehalose synthase & 5.4 .99 .15 & 13 \\
\hline & Trehalose synthase & 5.4 .99 .16 & 13 \\
\hline \multirow[t]{2}{*}{$\mathrm{HATs}^{a}$} & rBAT protein & --- & 13 \\
\hline & 4F2he antigen & --- & 13 \\
\hline
\end{tabular}

${ }^{a}$ HATs means the heteromeric amino acid transporter proteins. Adapted from JANECEK (2009). 

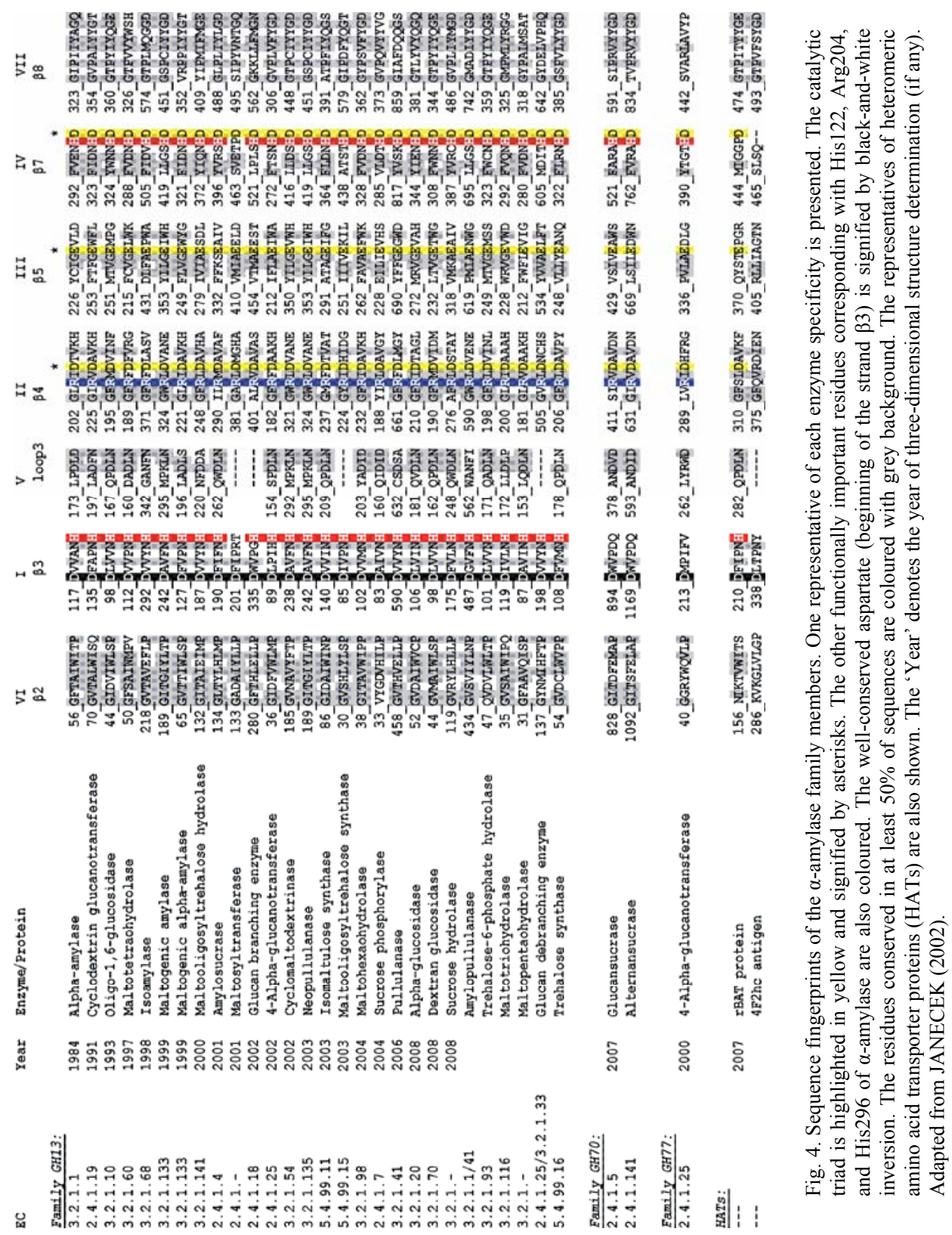
The active site of these enzymes is localised at the C-terminal end of the TIMbarrel (MATSUURA et al., 1984, QIAN et al., 1993; KADZIOLA et al., 1994; LINDEN et al., 2003). Comparison of known tertiary structures of various $\alpha$-amylase family members with sequence alignments have shown that differences in specificity result from different variation of substrate binding at the $\beta->\alpha$ loops (SVENSSON, 1994; JANECEK, 1997). Also the active-site cleft is not of the same shape in each case (KAMITORI et al., 1999; PRZYLAS et al., 2000), despite the fact it always contains the same catalytic triad accompanied, however, by several additional residues depending on a given enzyme specificity (MATSUURA, 2002). Differences especially in the length, sequence and secondary structure have also been seen within the domain B protruding out of the catalytic TIM-barrel in the place of the loop 3 (JESPERSEN et al., 1991, 1993). It was pointed out that these differences may be directly related to enzyme specificity (JANECEK et al., 1997). With regard to domain C succeeding the catalytic TIM-barrel, this domain could contribute to the overall catalytic domain stability by shielding the hydrophobic residues of the barrel (KATSUYA et al., 1998).

As far as the conserved sequence regions of the $\alpha$-amylase family are concerned (Fig. 4), four of them (the regions I, II, III and IV) belong to the best known regions established more than 20 years ago, whereas the three additional ones (the regions $\mathrm{V}$, VI and VII) were identified more recently. The former regions (FRIEDBERG, 1983; NAKAJIMA et al., 1986; MACGREGOR et al., 2001), positioned near the C-termini of the $\beta$-strands $\beta 3, \beta 4, \beta 5$ and $\beta 7$ of the catalytic TIM-barrel, contain most of the functionally important residues including the catalytic triad (Fig. 4). The latter regions (JANECEK, 1992, 1994a,b, 1995, 2002), located near the C-terminal end of domain B and of $\beta$-strands $\beta 2$ and $\beta 8$, cover the features distinguishing the individual enzyme specificities from each other. Even the absence of the fifth conserved sequence region, for example, may be used as a feature characteristic of a given specificity (JANECEK, 2000).

Although the basic arrangement of the $\alpha$-amylase family members is the same counting the three domains A, B and C (Fig. 3a), it should be taken into account that there are some family members that contain additional $\mathrm{C}$ - and/or $\mathrm{N}$-terminal domains, for example cyclodextrin glucanotransferase (KLEIN and SCHULZ, 1991) and neopullulanase (HONDOH et al., 2003). They may play various and still not completely recognised functions, but most of them have been anticipated to be involved in binding starch (glycogen, pullulan) and related substrate analogues. These non-catalytic domains were in many cases confirmed to have this property and thus have been called starch-binding domains (PENNINGA et al., 1995; SORIMACHI et al., 1997). It was found that starch-binding domain disrupts the starch surface and thus increases the effect of the amylolytic hydrolysis (SOUTHALL et al., 1999). Within the CAZy server (Fig. 1), these motifs have been classified into the CBM (carbohydratebinding module) families (CANTAREL et al., 2009). At present, nine families of starch-binding domains are known: CBM20, CBM21, CBM25, CBM26, CBM34, CBM41, CBM45, CBM48, and CBM53. The motifs from the family CBM20 belong to most intensively studied starch-binding domains (SVENSSON et al., 1989; JANECEK and SEVCIK, 1999; RODRIGUEZ-SANOJA et al., 2005; MACHOVIC and JANECEK, 2006a). Based on a detailed bioinformatics analysis it was suggested 
to establish a common CBM clan from the families CBM20 and CBM21 (MACHOVIC et al., 2005) and the motifs classified recently into the families CBM48 and CBM53 could also join the proposed CBM clan (MACHOVIC and JANECEK, 2006b, 2008).

\subsection{Glycoside hydrolase families GH70 and GH77}

The family GH70 contains the sucrose-utilising glucosyltransferases (glucansucrase and alternansucrase) that possess a circularly permuted version of the $\alpha$-amylase-type catalytic TIM-barrel (MACGREGOR et al., 1996). The first element of the GH70-type barrel is the $\alpha$-helix equivalent to helix $\alpha 3$ of the $\alpha$-amylase-type TIM-barrel, whereas the last element is the $\beta$-strand equivalent to strand $\beta 3$ of $\alpha$ amylases (Fig. 5). This means that instead of E1-H1-E2-H2 ...E8-H8 present in $\alpha-$ amylases (and overall in both the families GH13 and GH77), in GH70 glucosyltransferases there is $\mathrm{H} 3-\mathrm{E} 4-\mathrm{H} 4-\mathrm{E} 5 \ldots \mathrm{H} 2-\mathrm{E} 3$, where $\mathrm{E}$ and $\mathrm{H}$ stand for $\beta$ strand and $\alpha$-helix, respectively (MACGREGOR et al., 1996). The glucansucrases are usually large multidomain proteins occurring exclusively in lactic acid bacteria (VAN HIJUM et al., 2006).

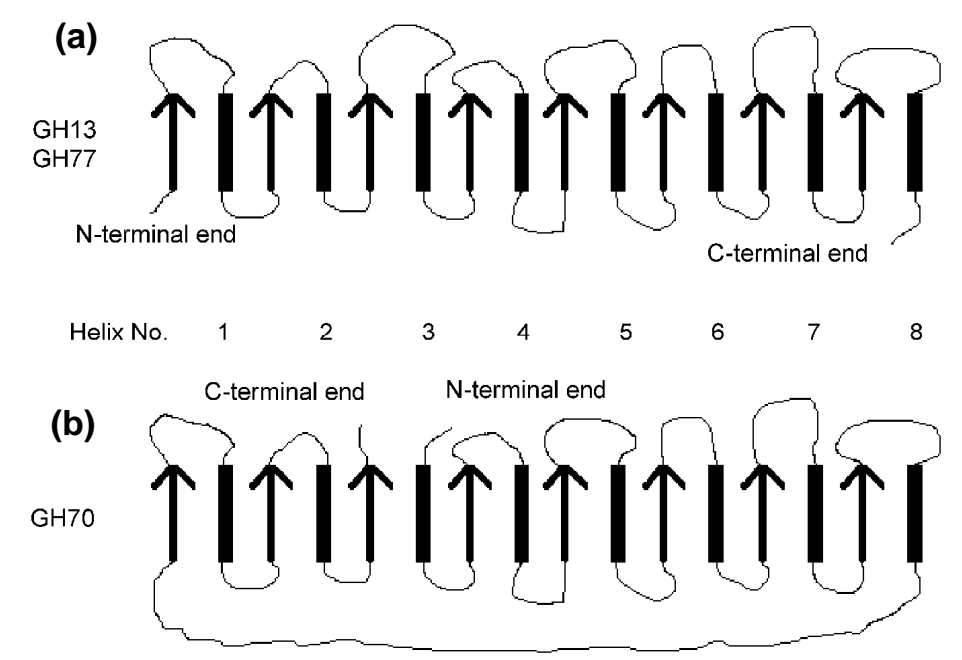

Fig. 5. The arrangement of the secondary structure elements in GH70 with respect to GH13 $\alpha$-amylase type TIM-barrel. (a) Typical "ordinary" TIM-barrel present in the members of the family GH13 (and also GH77); (b) circularly permuted version of the family GH70. The helices are represented by black rectangles and the strands are shown as arrows. The order of the helices in the GH13 (and GH77) is 12345678 from the Nterminal end of the protein, whereas in the GH70 the order is 34567812. Adapted from MACGREGOR (2005)

The structure/function relationships within the family GH70 and its relatedness to the main $\alpha$-amylase family GH13 were recently elucidated by determining the tertiary structure of the GH70 glucansucrase from Leuconostoc mesenteroides (PIJNING et 
al., 2008) that has confirmed the previous predictions concerning the circular permutation (Fig. 5). The solved structure interestingly revealed that the enzyme adopts the so-called "U-fold" domain arrangement so that 4 of the 5 domains are formed by combining an $\mathrm{N}$ - and a C-terminal part of the polypeptide chain (DIJKSTRA et al., 2007).

The family GH77 contains only one enzyme specificity, the amylomaltase (Table 1), known also as 4- $\alpha$-glucanotransferase in bacteria (TERADA et al., 1999) and archaeons (KAPER et al., 2005) or disproportionating enzyme (D-enzyme) in plants (TAKAHA et al., 1993). They exhibit a lower degree of sequence similarity to the family GH13 (Fig. 4) and the main feature characteristic for the GH77 members is the lack of domain C (PRZYLAS et al., 2000) succeeding typically the catalytic TIMbarrel in GH13 (Fig. 3). The GH77 structure contains several, mainly $\alpha$-helical insertions that can be divided into three subdomains (Fig. 6): (i) subdomain B1 corresponds with GH13 domain B; (ii) subdomain B2 is unique for the GH77 amylomaltases; and (iii) subdomain B3 is equivalent to GH13 domain C (STRATER et al., 2002).

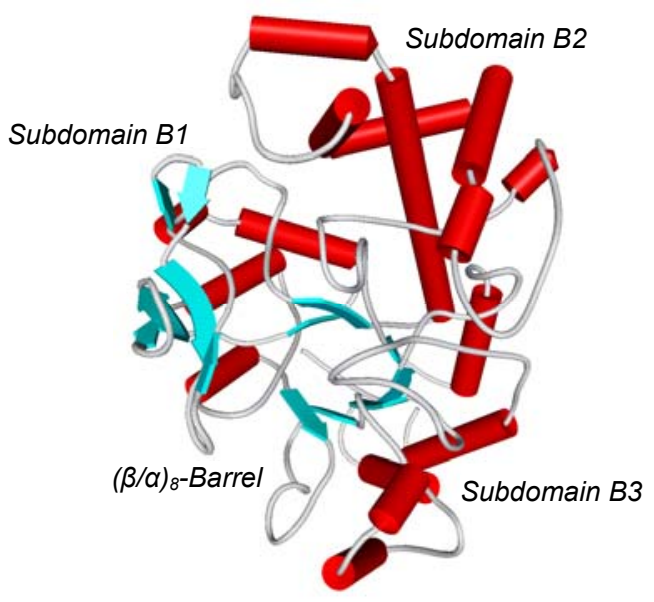

Fig. 6. Three-dimensional structure of GH77 amylomaltase from Thermus aquaticus (1CWY; Przylas et al., 2000).

The interest in the family GH77 was recently increased by revealing the putative amylomaltases from a few borreliae that exhibited in their amino acid sequences the non-GH77 features (GODANY et al., 2008). It was especially the arginine positioned two residues before the catalytic nucleophile in the conserved sequence region II (Fig. 4) that was recognized to be replaced naturally by a lysine in the GH77 amylomaltaselike protein from Borrelia burgdorferi (MACHOVIC and JANECEK, 2003). This arginine was otherwise considered to belong to the four residues conserved invariantly throughout the $\alpha$-amylase family, i.e. the entire clan GH-H (JANECEK, 2002). The exclusive (i.e. the non-GH77) sequence features present in GH77-like proteins from borreliae have already been confirmed as well as it was determined that the $B$. 
burgdorferi GH77 amylomaltase-like protein exhibits a typical amylomaltase activity, i.e. the enzyme catalyzes both the hydrolysis of maltooligosaccharides and formation of their transglycosylation products (GODANY et al., 2008). Based on the bioinformatics analysis of various $\mathrm{GH} 77$ real and hypothetical amylomaltases, some of the borrelial GH77-like proteins were suggested to exhibit an intermediary character within this family (JANECEK, 2008).

\subsection{Glycoside hydrolase families GH31 and GH57}

The families GH31 and GH57 are not the members of the clan GH-H, i.e. they do not belong to the $\alpha$-amylase family in terms as it is widely accepted (MACGREGOR et al., 2001), but they both deserve some attention here since they contain similar enzyme specificities ( $\alpha$-amylase, $\alpha$-glucosidase, amylopullulanase, $4-\alpha$ glucanotransferase, branching enzyme, etc.).

The family GH31 contains, in addition to the above-mentioned $\alpha$-glucosidases (EC 3.2.1.20 similar to GH13), also $\alpha$-xylosidases and $\alpha$-glucan lyases (FRANDSEN and SVENSSON, 1998; LEE et al., 2005; KANG et al., 2008). Although it employs the retaining mechanism (Fig. 2a) and its members adopt the catalytic TIM-barrel domain (Fig. 7a) similar to that adopting in the $\alpha$-amylase family (LOVERING et al., 2005;

(a)

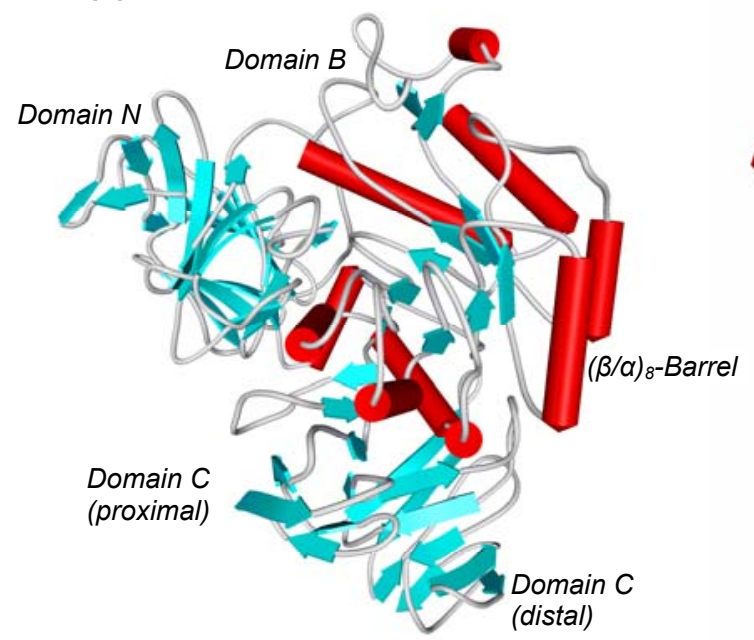

(b)

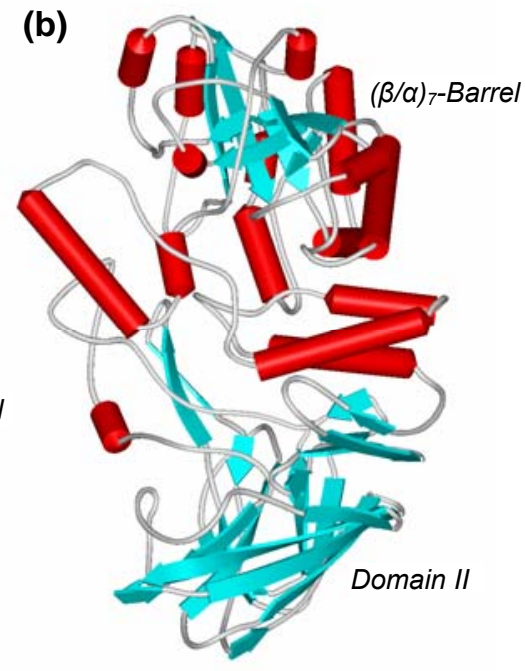

Fig. 7. Three-dimensional structure of (a) GH31 $\alpha$-xylosidase from Escherichia coli (1XSI; Lovering et al., 2005 ) and (b) GH57 4- $\alpha$-glucanotransferase from Thermococcus litoralis (1K1W; Imamura et al., 2003).

ERNST et al., 2006; SIM et al., 2008) with even the corresponding catalytic nucleophile (RIGDEN, 2002), the family GH31 has not joined the clan GH-H. One of the reasons is the difference in the proton donors used in $\mathrm{GH} 31$ and $\mathrm{GH}-\mathrm{H}$ 
(MATSUURA et al., 1984; UITDEHAAG et al., 1999; LOVERING et al., 2005). Based on a detailed bioinformatics study, an idea on the so-called remote homologies between the family GH31 and clan GH-H was proposed recently (JANECEK et al., 2007) indicating a possibility to create a level of evolutionary hierarchy higher than a clan.

As far as the family GH57 is concerned, it contains several enzyme specificities that are also members of the main $\alpha$-amylase family, only the $\alpha$-galactosidase (EC 3.2.1.22) being different (JANECEK, 2005; MURAKAMI et al., 2006). It also employs the retaining mechanism, but due to a different catalytic domain - an incomplete version of a TIM-barrel, i.e. a $(\beta / \alpha)_{7}$-barrel (Fig. $7 \mathrm{~b}$ ) and catalytic machinery (IMAMURA et al., 2003; DICKMANNS et al., 2006) - it should be evolutionarily more distantly related to GH13 than is the family GH31 (JANECEK, 1998). Moreover, GH57 exhibits its own conserved sequence regions (ZONA et al., 2004) that are different from those characteristic for the clan GH-H (JANECEK, 2002).

\section{4. $\alpha$-Amylases from archaebacteria and plants}

At present it is well-known and accepted that plant and archaeal $\alpha$-amylases from the family GH13 are sequentially similar and evolutionarily related. This remarkable finding was first observed ten years ago (JANECEK et al., 1999; JONES et al., 1999). Before the first GH13 $\alpha$-amylases from Archaea became available, the plant $\alpha$ amylases were positioned in the evolutionary tree (Fig. 8) on a branch next to the cluster of bacterial liquefying and intracellular $\alpha$-amylases represented by bacilli and enterobacteria, respectively (JANECEK, 1994b).

\subsection{Similarities and differences}

The first detailed bioinformatics study focused on the archaeal $\alpha$-amylases and their counterparts from a wide spectrum of remaining living organisms from Bacteria and Eucarya revealed (JANECEK et al., 1999) that the sequence features exclusive for the $\alpha$-amylases from hyperthermophilic archaeons are present also and almost only in the plant $\alpha$-amylases (Fig. 9). These features are as follows (JANECEK et al., 1999): (i) Ile107 (Thermococcus hydrothermalis $\alpha$-amylase numbering; LEVEQUE et al., 2000a) succeeding the conserved aspartate in the conserved sequence region region I (strand $\beta 3$ ); (ii) (Ala194)-Trp195 at the beginning, Tyr199 in the middle and Gly202 at the end of the region II (strand $\beta 4$ ); (iii) Ala219 succeeding the conserved tryptophane and Tyr223-Trp224 succeeding the catalytic proton donor (Glu222) in the region III (strand $\beta 5$ ); (iv) Ala286 in the region IV (strand $\beta 7$ ); (v) Ile196 in the region V (located within the loop3, i.e. domain B); (vi) Ile42 succeeding the conserved glycine at the beginning and dipeptide Pro48-Pro49 at the end of the region VI (strand $\beta 2$ ); and (vii) Gln309 succeeding the conserved glycine at the beginning, tripeptide Ile312Phe313-Tyr314 in the middle and Asp316 at the end of the region VII (strand $\beta 8$ ). It is worth mentioning that some of the above-mentioned residues have already been recognised as functionally important residues (KADZIOLA et al., 1998; LINDEN et 


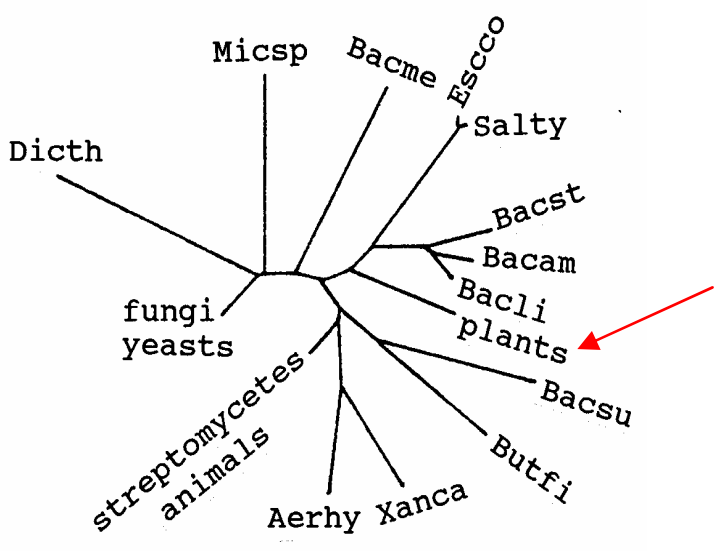

Fig. 8. The evolutionary tree of microbial (including fungi and yeasts), plant and animal $\alpha$-amylases. The bacterial sources are abbreviated as follows: Dicth, Dictyoglomus thermophilum; Micsp, Micrococcus sp.; Bacme, Bacillus megaterium; Escco, Escherichia coli; Salty, Salmonella typhimurium; Bacst, Bacillus stearothermophilus; Bacam, Bacillus amyloliquefaciens; Bacli, Bacillus licheniformis; Bacsu, Bacillus subtilis; Butfi, Butyrivibrio fibrisolvens, Xanca, Xanthomonas campestris; Aerhy, Aeromonas hydrophila. The tree does not contain any archaeal $\alpha$-amylase since at the beginning of 90 s of the previous century no sequence of an archaeal $\alpha$-amylase was available. The red arrow indicates the the cluster of plant $\alpha$ amylases. Adapted from JANECEK (1994b).
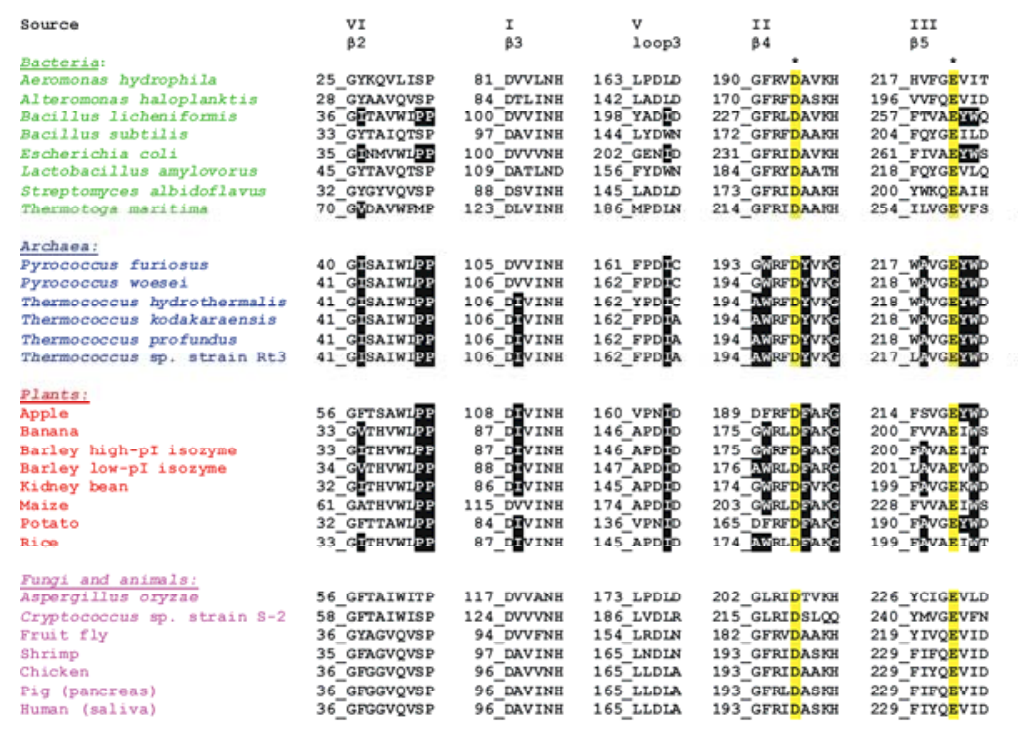

$\underset{B v}{\mathrm{IV}}$

$\operatorname{Vir}_{B 8}^{\mathrm{VIX}}$

105_DVVINB

186 MPDLA

214_GFRTDAAKH

200 Y YWKOEAII
254 - ILVGEVES

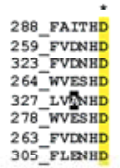

323 GSPLV"

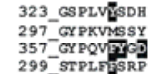

299_TRPLFFRP

313 _SVPLFPRP

$\begin{array}{ll}263 \text { FVDNHD } & 297 \text { _GSPVHSGY } \\ 05 \text { - FLEAHD } & 349 \text { - GPVIIYYGG }\end{array}$

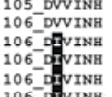

161_FPDIC
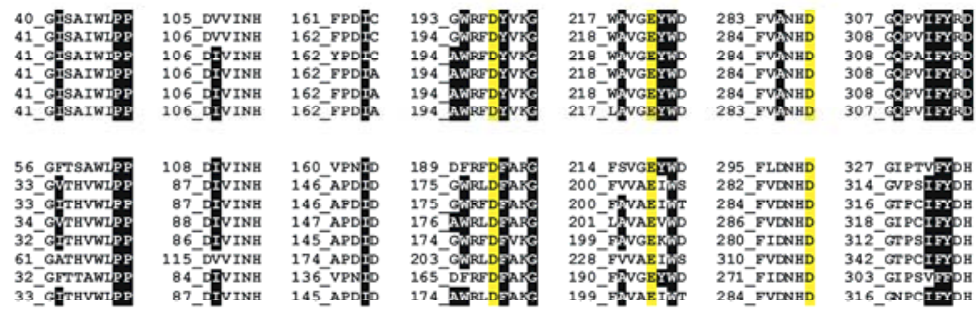

295_FLDNHD

$282-$ FVDNHD

$284{ }^{-}$FVDNHD
$286^{-}$FVDNHD
$280^{-}$

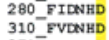

$271^{-}$FIDNHD

327_GIPTYFPB

56-GFTAIWTTP

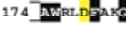

58 GFTAIWISP
36 GYAGVQVSP

36 GYAGVQVSP
35 GEMGVQVSP
36 G

36 GFGGVVSP
$36_{\text {_GFGVQVSP }}$

124_DVVANG

173-LPDID

202 _GLRIDTVKH

199- DMVATI

312 -GT

303 GIPS

316_GIPSVPPH

66- DAVYNB 165 -

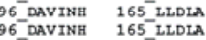

182_GFRVDAAKH

193 _GFRIDASKR

226_ YCIGEVLD

292_FVENHD

323_GIPI TMGQ

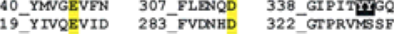

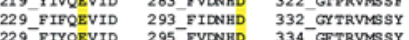

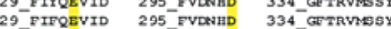

334 GETRMMSSY

Fig. 9. Sequence fingerprints of $\alpha$-amylases. The enzymes represent the individual taxonomic sources with focus on Archaea and plants. The sequence features characteristic of the archaeal $\alpha$-amylases are highlighted in black-and-white inversion. The catalytic triad is signified by asterisks and yellow highlighting. Adapted from JANECEK (2008). 
al., 2003). Thus for example the glycine from the region II (Gly202 of the archaeal $\alpha$ amylase) serves as a specific ligand for calcium ion and the tryptophane from the region III (Trp224 of the archaeal $\alpha$-amylase) forms a stacking interaction with one of the acarbose rings bound in the active site in the complex structure of barley $\alpha$ amylase with acarbose (KADZIOLA et al., 1998). These residues should play the same roles in the structure of the archaeal $\alpha$-amylase from Pyrococcus woese $i$ (LINDEN et al., 2003).

The close sequence similarity between the $\alpha$-amylases from Archaea and plants has evoked the idea on a possibility to reveal the factors responsible for the high thermostability of the archaeal $\alpha$-amylases that exhibit the temperature optima around and above $80{ }^{\circ} \mathrm{C}$ (LEVEQUE et al., 2000b; BERTOLDO and ANTRANIKIAN, 2002). The plant enzymes are generally substantially less thermostable. It is worth mentioning that on the one side the archaeal and plant $\alpha$-amylases contain the common sequence features that discriminate them from the remaining sources, but on the other side they have to possess the additional sequence features that should enable one to distinguish them from each other, e.g., the alanine from the region IV (Ala286 of the archaeal $\alpha$-amylase) that has no correspondence in the plant counterparts (Fig. 4). Such specific differences could be utilized in an effort to identify the molecular basis of high thermostability of the archaeal $\alpha$-amylases via the approaches of site-directed mutagenesis and protein design.

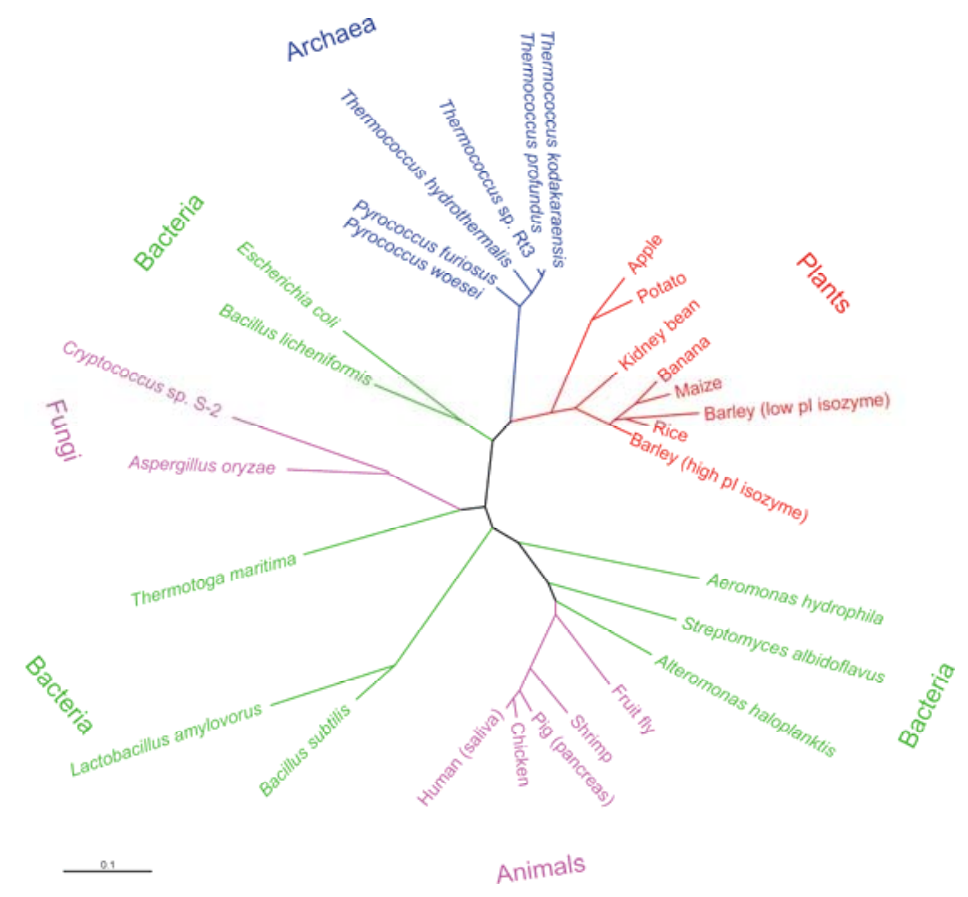

Fig. 10. The evolutionary tree of $\alpha$-amylases. The tree reflects the conserved sequence fingerprints of $\alpha$ amylases (Fig. 9). Adapted from JANECEK (2008). 


\subsection{Evolutionary relatedness}

The close evolutionary relatedness of the $\alpha$-amylases from Archaea and plants from the family GH13 is shown in Figure 10. The GH13 as one of the largest GH families (CANTAREL et al., 2009) has recently been divided into the subfamilies (STAM et al., 2006), the plant and archaeal $\alpha$-amylases being placed into the subfamilies GH13_6 and GH13_7, respectively. With regard to the $\alpha$-amylases most closely related to those from plants and Archaea (Fig. 10), these are the bacterial enzymes from Bacillus licheniformis (YUUKI et al., 1985) and Escherichia coli (RAHA et al., 1992) that represent the liquefying and intracellular $\alpha$-amylases, respectively, as observed originally (JANECEK, 1994b). It should be noted, however, that the close evolutionary relationships between the $\alpha$-amylases from Archaea and plants illustrated here only for a limited sample of living organisms (Fig. 10) has been confirmed also in the more recent evolutionary trees comparing a wider spectrum of taxonomic sources including novel groups of $\alpha$-amylases from bacteria (DA LAGE et al., 2004) and fungi (VAN DER KAAIJ et al., 2007).

Acknowledgements: This work was supported in part by the grants No. 1/4363/07 and 2/0114/08 from the Slovak grant agency VEGA and the project AV-4/2023/08 from the Ministry of Education of the Slovak Republic.

\section{References}

ALESHIN, A.E., GOLUBEV, A., FIRSOV, L.M., HONZATKO, R.B.: Crystal structure of glucoamylase from Aspergillus awamori var. X100 to $2.2 \AA$ resolution. J. Biol. Chem., 267, 1992, 19291-19298.

BERTOLDO, C., ANTRANIKIAN, G.: Starch-hydrolyzing enzymes from thermophilic archaea and bacteria. Curr. Opin. Chem. Biol., 6, 2002, 151-160.

CANTAREL, B.L., COUTINHO, P.M., RANCUREL, C., BERNARD, T., LOMBARD, V., HENRISSAT, B.: The Carbohydrate-Active enZymes database (CAZy): an expert resource for glycogenomics. Nucleic Acids Res., 37, 2009, 233 238.

COUTINHO, P.M., REILLY, P.J.: Glucoamylase, structural, functional, and evolutionary relationships. Proteins, 29, 1997, 334-347.

DA LAGE, J.L., FELLER, G., JANECEK, S.: Horizontal gene transfer from Eukarya to bacteria and domain shuffing: the $\alpha$-amylase model. Cell. Mol. Life Sci., 61, 2004, 97-109.

DAVIES, G.J., WILSON, K.S., HENRISSAT, B.: Nomenclature for sugar-binding subsites in glycosyl hydrolases. Biochem. J., 321, 1997, 557-559.

DICKMANNS, A., BALLSCHMITER, M., LIEBL, W., FICNER, R.: Structure of the novel $\alpha$-amylase AmyC from Thermotoga maritima. Acta Crystallogr. D Biol. Crystallogr., 62, 2006, 262-270.

DIJKSTRA, B.W., VUJICIC-ZAGAR, A., PIJNING, T., KRALJ, S., DIJKHUIZEN, L.: Structural and functional characterization of a glucansucrase $(\triangle N-G T F 180)$ from Lactobacillus reuteri 180, a GH family 70 enzyme. Abstract Book of the $3^{\text {rd }}$ Symposium on the Alpha-Amylase Family. Smolenice Castle, Slovakia, Sep 2327, 2007, 15. 
ERNST, H.A., LO LEGGIO, L., WILLEMOES, M., LEONARD, G., BLUM, P., LARSEN, S.: Structure of the Sulfolobus solfataricus $\alpha$-glucosidase: implications for domain conservation and substrate recognition in GH31. J. Mol. Biol., 358, 2006, 1106-1124.

FARBER, G.K., PETSKO, G.A.: The evolution of $\alpha / \beta$ barrel enzymes. Trends Biochem. Sci., 15, 1990, 228-234.

FRANDSEN, T.P., SVENSSON, B.: Plant $\alpha$-glucosidases of the glycoside hydrolase family 31. Molecular properties, substrate specificity, reaction mechanism, and comparison with family members of different origin. Plant Mol. Biol., 37, 1998, 113.

FRIEDBERG, F.: On the primary structure of amylases. FEBS Lett., 152, 1983, 139140.

GODANY, A., VIDOVA, B., JANECEK, S.: The unique glycoside hydrolase family 77 amylomaltase from Borrelia burgdorferi with only catalytic triad conserved. FEMS Microbiol. Lett., 284, 2008, 84-91.

HENRISSAT, B.: A classification of glycosyl hydrolases based on amino acid sequence similarities. Biochem. J., 280, 1991, 309-316.

HONDOH, H., KURIKI, T., MATSUURA, Y.: Three-dimensional structure and substrate binding of Bacillus stearothermophilus neopullulanase. J. Mol. Biol., 326, 2003, 177-188.

IMAMURA, H., FUSHINOBU, S., YAMAMOTO, M., KUMASAKA, T., JEON, B.S., WAKAGI, T., MATSUZAWA, H.: Crystal structures of 4- $\alpha-$ glucanotransferase from Thermococcus litoralis and its complex with an inhibitor. J. Biol. Chem., 278, 2003, 19378-19386.

JANECEK, S.: New conserved amino acid region of $\alpha$-amylases in the third loop of their $(\beta / \alpha)_{8}$-barrel domains. Biochem. J., 288, 1992, 1069-1070.

JANECEK, S.: Parallel $\beta / \alpha$-barrels of $\alpha$-amylase, cyclodextrin glycosyltransferase and oligo-1,6-glucosidase versus the barrel of $\beta$-amylase: evolutionary distance is a reflection of unrelated sequences. FEBS Lett., 353, 1994a, 119-123.

JANECEK, S.: Sequence similarities and evolutionary relationships of microbial, plant and animal $\alpha$-amylases. Eur. J. Biochem., 224, 1994b, 519-524.

JANECEK, S.: Close evolutionary relatedness among functionally distantly related members of the $(\alpha / \beta)_{8}$-barrel glycosyl hydrolases suggested by the similarity of their fifth conserved sequence region. FEBS Lett., 377, 1995, 6-8.

JANECEK, S.: $\alpha$-Amylase family: molecular biology and evolution. Progr. Biophys. Mol. Biol., 67, 1997, 67-97.

JANECEK, S.: Sequence of archaeal Methanococcus jannaschii $\alpha$-amylase contains features of families 13 and 57 of glycosyl hydrolases: a trace of their common ancestor? Folia Microbiol., 43, 1998, 123-128.

JANECEK, S.: Structural features and evolutionary relationships in the $\alpha$-amylase family. In: M. OHNISHI, T. HAYASHI, S. ISHIJIMA, T. KURIKI (Eds.) Glycoenzymes. Japan Scientific Societies Press, Tokyo, 2000, 19-54.

JANECEK, S.: How many conserved sequence regions are there in the $\alpha$-amylase family? Biologia, 57 (Suppl. 11), 2002, 29-41.

JANECEK, S.: Amylolytic families of glycoside hydrolases: focus on the family GH57. Biologia, 60 (Suppl. 16), 2005, 177-184. 
JANECEK, S.: Sequence fingerprints in the evolution of the $\alpha$-amylase family. In: K.H. PARK (Ed.) Carbohydrate-active enzymes: structure, function and applications. Woodhead Publishing, Ltd., Cambridge, 2008, 45-63.

JANECEK, S.: Bioinformatics of the $\alpha$-amylase family. In: A. PANDEY, C. LARROCHE, C.R. SOCCOL, C.G. DUSSAP (Eds.) New horizons in biotechnology. Asiatech Publishers, Inc., New Delhi, 2009, 37-52.

JANECEK, S., LEVEQUE, E., BELARBI, A., HAYE, B.: Close evolutionary relatedness of $\alpha$-amylases from Archaea and plants. J. Mol. Evol., 48, 1999, 421426.

JANECEK, S., SEVCIK, J.: The evolution of starch-binding domain. FEBS Lett., 456, $1999,119-125$.

JANECEK, S., SVENSSON, B., HENRISSAT, B.: Domain evolution in the $\alpha$ amylase family. J. Mol. Evol., 45, 1997, 322-331.

JANECEK, S., SVENSSON, B., MACGREGOR, E.A.: A remote but significant sequence homology between glycoside hydrolase clan GH-H and family GH31. FEBS Lett., 581, 2007, 1261-1268.

JESPERSEN, H.M., MACGREGOR, E.A., HENRISSAT, B., SIERKS, M.R., SVENSSON, B.: Starch- and glycogen-debranching and branching enzymes: prediction of structural features of the catalytic $(\beta / \alpha)_{8}$-barrel domain and evolutionary relationship to other amylolytic enzymes. J. Protein Chem., 12, 1993, 791-805.

JESPERSEN, H., MACGREGOR, E.A., SIERKS. M.R., SVENSSON, B.: Comparison of the domain-level organization of starch hydrolases and related enzymes. Biochem. J., 280, 1991, 51-55.

JONES, R.A., JERMIIN, L.S., EASTEAL, S., PATEL, B.K., BEACHAM, I.R.: Amylase and 16S rRNA genes from a hyperthermophilic archaebacterium. J. Appl. Microbiol., 86, 1999, 93-107.

KADZIOLA, A., ABE, J., SVENSSON, B., HASER, R.: Crystal and molecular structure of barley $\alpha$-amylase. J. Mol. Biol., 1994, 239, 104-121.

KADZIOLA, A., SOGAARD, M., SVENSSON, B., HASER, R.: Molecular structure of a barley $\alpha$-amylase-inhibitor complex: implications for starch binding and catalysis. J. Mol. Biol., 278, 1998, 205-217.

KAMITORI, S., KONDO, S., OKUYAMA, K., YOKOTA, T., SHIMURA, Y., TONOZUKA, T., SAKANO, Y.: Crystal structure of Thermoactinomyces vulgaris R-47 $\alpha$-amylase II (TVA II) hydrolyzing cyclodextrins and pullulan at $2.6 \AA$ resolution. J. Mol. Biol., 287, 1999, 907-921.

KANG, M.S., OKUYAMA, M., YAOI, K., MITSUISHI, Y., KIM, Y.M., MORI, H., KIMURA, A.: Glycoside hydrolase family 31 Escherichia coli $\alpha$-xylosidase. Biocatal. Biotransform., 26, 2008, 96-103.

KAPER. T., TALIK, B., ETTEMA, T.J., BOS, H., VAN DER MAAREL, M.J., DIJKHUIZEN, L.: Amylomaltase of Pyrobaculum aerophilum IM2 produces thermoreversible starch gels. Appl. Environ. Microbiol., 71, 2005, 5098-5106.

KATSUYA, Y., MEZAKI, Y., KUBOTA, M., MATSUURA, Y.: Three-dimensional structure of Pseudomonas isoamylase at $2.2 \AA$ resolution. J. Mol. Biol., 281, 1998, 885-897. 
KLEIN, C., SCHULZ, G.E.: Structure of cyclodextrin glycosyltransferase refined at 2.0 Å resolution. J. Mol. Biol., 217, 1991, 737-750.

KURIKI, T., IMANAKA, T.: The concept of the $\alpha$-amylase family: structural similarity and common catalytic mechanism. J. Biosci. Bioeng., 87, 1999, 557-565.

LEE, S.S., YU, S., WITHERS, S.G.: Mechanism of action of exo-acting $\alpha$-1,4-glucan lyase: a glycoside hydrolase family 31 enzyme. Biologia, 60 (Suppl. 16), 2005, 137-148.

LEGIN, E., COPINET, A., DUCHIRON, F.: Production of thermostable amylolytic enzymes by Thermococcus hydrothermalis. Biotechnol. Lett., 20, 1998, 363-367.

LEVEQUE, E., HAYE, B., BELARBI, A.: Cloning and expression of an $\alpha$-amylase encoding gene from the hyperthermophilic archaebacterium Thermococcus hydrothermalis and biochemical characterisation of the recombinant enzyme. FEMS Microbiol. Lett., 186, 2000a, 67-71.

LEVEQUE, E., JANECEK, S., BELARBI, A., HAYE, B.: Thermophilic archaeal amylolytic enzymes. Enzyme Microb. Technol., 26, 2000b, 2-13.

LINDEN, A., MAYANS, O., MEYER-KLAUCKE, W., ANTRANIKIAN, G., WILMANNS, M.: Differential regulation of a hyperthermophilic $\alpha$-amylase with a novel (Ca,Zn) two-metal center by zinc. J. Biol. Chem., 278, 2003, 9875-9884.

LOVERING, A.L., LEE, S.S., KIM, Y.W., WITHERS, S.G., STRYNADKA, N.C.J.: Mechanistic and structural analysis of a family $31 \alpha$-glycosidase and its glycosylenzyme intermediate. J. Biol. Chem., 280, 2005, 2105-2115.

MACGREGOR, E.A.: An overview of clan GH-H and distantly related families. Biologia, 60 (Suppl. 16), 2005, 5-12.

MACGREGOR, E.A., JANECEK, S., SVENSSON, B.: Relationship of sequence and structure to specificity in the $\alpha$-amylase family of enzymes. Biochim. Biophys. Acta, 1546, 2001, 1-20.

MACGREGOR, E.A., JESPERSEN, H.M., SVENSSON, B.: A circularly permuted $\alpha-$ amylase-type $\alpha / \beta$-barrel structure in glucan-synthesizing glucosyltransferases. FEBS Lett., 378, 1996, 263-266.

MACGREGOR, E.A., SVENSSON, B.: A super-secondary structure predicted to be

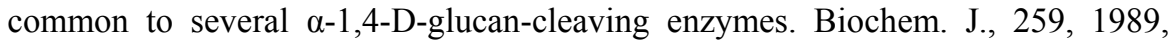
145-152.

MACHOVIC, M., JANECEK, S.: The invariant residues in the $\alpha$-amylase family: just the catalytic triad. Biologia, 58, 2003, 1127-1132.

MACHOVIC, M., JANECEK, S.: Starch-binding domains in the post-genome era. Cell. Mol. Life Sci., 63, 2006a, 2710-2724.

MACHOVIC, M., JANECEK, S.: The evolution of putative starch-binding domains. FEBS Lett., 580, 2006b, 6349-6356.

MACHOVIC, M., JANECEK, S.: Domain evolution in the GH13 pullulanase subfamily with focus on the carbohydrate-binding module family 48 . Biologia, 63 , 2008, 1053-1064.

MACHOVIC, M., SVENSSON, B. MACGREGOR, E.A., JANECEK, S.: A new clan of CBM families based on bioinformatics of starch-binding domains from families CBM20 and CBM21. FEBS J., 272, 2005, 5497-5513. 
MATSUURA, Y.: A possible mechanism of catalysis involving three essential residues in the enzymes of $\alpha$-amylase family. Biologia, 57 (Suppl. 11), 2002, 2127.

MATSUURA, Y., KUSUNOKI, M., HARADA, W., KAKUDO, M.: Structure and possible catalytic residues of Taka-amylase A. J. Biochem., 95, 1984, 697-702.

MCCARTER, J.D., WITHERS, S.G.: Mechanisms of enzymatic glycoside hydrolysis. Curr. Opin. Struct. Biol., 4, 1994, 885-892.

MIKAMI, B., HEHRE, E.J., SATO, M., KATSUBE, Y., HIROSE, M., MORITA, Y., SACCHETTINI J.C.: The $2.0 \AA$ resolution structure of soybean $\beta$-amylase complexed with $\alpha$-cyclodextrin. Biochemistry, 32, 1993, 6836-6845.

MURAKAMI, T., KANAI, T., TAKATA, H., KURIKI, T., IMANAKA, T.: A novel branching enzyme of the GH-57 family in the hyperthermophilic archaeon Thermococcus kodakaraensis KOD1. J. Bacteriol., 188, 2006, 5915-5924.

NAKAI, H., OKUYAMA, M., KIM, Y.M., SABURI, W., WONGCHAWALIT, J., MORI, H., CHIBA, S., KIMURA, A.: Molecular analysis of $\alpha$-glucosidase belonging to GH-family 31. Biologia, 60 (Suppl. 16), 2005, 131-135.

NAKAJIMA, R., IMANAKA, T., AIBA, S.: Comparison of amino-acid-sequences of 11 different $\alpha$-amylases. Appl. Microbiol. Biotechnol., 23, 1986, 355-360.

PANDEY, A., NIGAM, P., SOCCOL, C.R., SOCCOL, V.T., SINGH, D., MOHAN, R.: Advances in microbial amylases. Biotechnol. Appl. Biochem., 31, 2000, $135-$ 152.

PENNINGA, D., VAN DER VEEN, B.A., KNEGTEL, M.R., VAN HIJUM, S.A., ROZEBOOM, H.J., KALK, K.H., DIJKSTRA, B.W., DIJKHUIZEN, L.: The raw starch-binding domain of cyklodextrin glycosyltransferase from Bacillus circulans strain 251. J. Biol. Chem., 271, 1996, 32777-32784.

PIJNING, T., VUJICIC-ZAGAR, A., KRALJ, S., EEUWEMA, W., DIJKHUIZEN, L., DIJKSTRA, B.: Biochemical and crystallographic characterization of a glucansucrase from Lactobacillus reuteri 180. Biocatal. Biotransform., 26, 2008, 12-17.

PRZYLAS, I., TOMOO, K., TERADA, Y., TAKAHA, T., FUJII, K., SAENGER, W., STRATER, N.: Crystal structure of amylomaltase from Thermus aquaticus, a glycosyltransferase catalysing the production of large cyclic glucans. J. Mol. Biol., 296, 2000, 873-886.

PUJADAS, G., RAMIREZ, F.M., VALERO, R., PALAU, J.: Evolution of $\beta$-amylase: patterns of variation and conservation in subfamily sequences in relation to parsimony mechanisms. Proteins, 25, 1996, 456-472.

QIAN, M., HASER, R., PAYAN, F.: Structure and molecular model refinement of pig pancreatic $\alpha$-amylase at $2.1 \AA$ resolution. J. Mol. Biol., 231, 1993, 785-799.RAHA, M., KAWAGISHI, I., MUELlER, V., KIHARA, M., MACNAB, R.M.: Escherichia coli produces a cytoplasmic $\alpha$-amylase, AmyA. J. Bacteriol., 174, 1992, 6644-6652.

RIGDEN D.J.: Iterative database searches demonstrate that glycoside hydrolase families 27, 31, 36 and 66 share a common evolutionary origin with family 13 . FEBS Lett., 53, 2002, 17-22. 
RODRIGUEZ-SANOJA, R., OVIEDO, N., SANCHEZ, S.: Microbial starch-binding domain. Curr. Opin. Microbiol., 8, 2005, 260-267.

SAUER, J., SIGURSKJOLD, B.W., CHRISTENSEN, U., FRANDSEN, T.P., MIRGORODSKAYA, E., HARRISON, M., ROEPSTORFF, P., SVENSSON, B.: Glucoamylase: structure/function relationships, and protein engineering. Biochim. Biophys. Acta, 1543, 2000, 275-293.

SIM, L., QUEZADA-CALVILlO, R., STERCHI, E.E., NICHOLS, B.L., ROSE, D.R.: Human intestinal maltase-glucoamylase: crystal structure of the N-terminal catalytic subunit and basis of inhibition and substrate specificity. J. Mol. Biol., 375, 2008, 782-792.

SORIMACHI, K., LE GAL-COEFFET, M.F., WILLIAMSON, G., ARCHER, D.B., WILLIAMSON, M.P.: Solution structure of the granular starch binding domain of Aspergillus niger glucoamylase bound to $\beta$-cyclodextrin. Structure, 15, 1997, 647661.

SOUTHALL, S.M., SIMPSON, P.J., GILBERT, H.J., WILLIAMSON, G., WILLIAMSON, M.P.: The starch-binding domain from glucoamylase disrupts the structure of starch. FEBS Lett., 447, 1999, 58-60.

STAM, M.R., DANCHIN, E.G., RANCUREL, C., COUTINHO, P.M., HENRISSAT, B.: Dividing the large glycoside hydrolase family 13 into subfamilies: towards improved functional annotations of $\alpha$-amylase-related proteins. Protein Eng. Des. Sel., 19, 2006, 555-562.

STRATER, N., PRZYLAS, I., SAENGER W., TERADA Y., FUJI, K., TAKAHA, T.: Structural basis of the synthesis of large cycloamyloses by amylomaltase. Biologia, 57 (Suppl. 11), 2002, 93-99.

SVENSSON, B.: Protein engineering in the $\alpha$-amylase family: catalytic mechanism, substrate specificity, and stability. Plant Mol. Biol., 25, 1994, 141-157.

SVENSSON, B., JESPERSEN, H., SIERKS, M., MACGREGOR, E.A.: Sequence homology between putative raw starch-binding domains from different starch degrading enzymes. Biochem. J., 264, 1989, 309-311.

TAKAHA, T., YANASE, M., OKADA, S., SMITH, S.M.: Disproportionating enzyme (4- $\alpha$-glucanotransferase; EC 2.4.1.25) of potato. Purification, molecular cloning, and potential role in starch metabolism. J. Biol. Chem., 268, 1993, 1391-1396.

TAKATA, H., KURIKI, T., OKADA, S., TAKESADA, Y., IIZUKA, M., MINAMIURA, N., IMANAKA, T.: Action of neopullulanase. Neopullulanase catalyzes both hydrolysis and transglycosyltaion at $\alpha-(1->4)-$ and $\alpha-(1->6)-$ glucosidic linkages. J. Biol. Chem., 267, 1992, 18447-18452.

TERADA, Y., FUJI, K., TAKAHA, T., OKADA, S.: Thermus aquaticus ATCC 33923 amylomaltase gene cloning and expression and enzyme characterization: production of cycloamylose. Appl. Environ. Microbiol., 65, 1999, 910-915.

UITDEHAAG, J.C.M., MOSI, R., KALK, K.H., VAN DER VEEN, B.A., DIJKHUIZEN, L., WITHERS, S.G., DIJKSTRA, B.W.: X-ray structures along the reaction pathway of cyclodextrin glycosyltransferase elucidate catalysis in the $\alpha$ amylase family. Nat. Struct. Biol., 6, 1999, 432-436.

VAN DER KAAIJ, R.M., JANECEK, S., VAN DER MAAREL, M.J., DIJKHUIZEN, L.: Phylogenetic and biochemical characterization of a novel cluster of intracellular fungal $\alpha$-amylase enzymes. Microbiology, 153, 2007, 4003-4015. 
VAN DER MAAREL, M.J.E.C., VAN DER VEEN, B., UITDEHAAG, J.C.M., LEEMHUIS, H., DIJKHUIZEN, L.: Properties and applications of starchconverting enzymes of the $\alpha$-amylase family. J. Biotechnol., 94, 2002, 137-155.

VAN HIJUM, S.A., KRALJ, S., OZIMEK, L.K., DIJKHUIZEN, L., VAN GEELSCHUTTEN, I.G.: Structure-function relationships of glucansucrase and fructansucrase enzymes from lactic acid bacteria. Microbiol. Mol. Biol. Rev., 70, 2006, 157-176.

VIHINEN, M., MANTSALA, P.: Microbial amylolytic enzymes. Crit. Rev. Biochem. Mol. Biol., 24, 1989, 329-418.

YUUKI, T., NOMURA, T., TEZUKA, H., TSUBOI, A., YAMAGATA, H., TSUKAGOSHI, N., UDAKA, S.: Complete nucleotide sequence of a gene coding for heat- and $\mathrm{pH}$-stable $\alpha$-amylase of Bacillus licheniformis: comparison of the amino acid sequences of three bacterial liquefying $\alpha$-amylases deduced from the DNA sequences. J. Biochem., 98, 1985, 1147-1156.

ZONA, R., CHANG-PI-HIN, F., O’DONOHUE, M.J., JANECEK, S.: Bioinformatics of the family 57 glycoside hydrolases and identification of catalytic residues in amylopullulanase from Thermococcus hydrothermalis. Eur. J. Biochem., 271, 2004, 2863-2872. 